\section{Antropologiczne i socjologiczne spojrzenie na postać Ducha Parakleta w mowach pożegnalnych Jezusa \\ (J 13 - 17)}

W mowach pożegnalnych Jezusa, skierowanych do najbliższych uczniów podczas ostatniej wieczerzy, z których relację pozostawia jedynie ewangelista Jan (J 13 - 17), znajduje się pięć wypowiedzi o Duchu Paraklecie. Bez wątpienia chodzi tutaj o postać Ducha Świętego, która w kontekście uprzednim tej Ewangelii pojawiała się już wielokrotnie: chrzest Jezusa $(1,29-34)$, dialog z Nikodemem wraz z komentarzem (3, 2-8. 31-36), dialog z Samarytanką (4, 19-26), słowa Jezusa są Duchem i życiem $(6,60-66)$, Duch jako strumienie wody żywej $(7,37-39)$. Postać Ducha Świętego pojawia się też dwukrotnie w tej Ewangelii w kontekście następującym po mowach pożegnalnych: Jezus przekazuje Ducha w chwili śmierci na krzyżu (19, 28-30), zmartwychwstały Chrystus przekazuje Ducha Świętego uczniom (20,19-23). W mowach pożegnalnych J 13 - 17 ów Duch

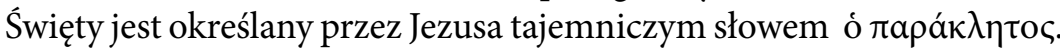
W proponowanym artykule chcemy spojrzeć na tę postać z punktu widzenia antropologii kulturowej i socjologii, gdyż w naszej opinii zastosowanie takiej optyki pozwala najpełniej zrozumieć tożsamość

\footnotetext{
1 Janusz Kręcidło MS, profesor tytularny nauk teologicznych, kierownik Katedry Egzegezy Nowego Testamentu na UKSW w Warszawie, członek Rady Doskonałości Naukowej, członek Komitetu Nauk Teologicznych Polskiej Akademii Nauk.
} 
i funkcję Ducha Parakleta. Zanim jednak ukażemy Parakleta w tej perspektywie, skrótowo przedstawimy główne kierunki interpretacji tej postaci we współczesnej egzegezie.

\section{Synteza współczesnych poglądów odnośnie do tożsamości Ducha Parakleta w J 13 - 17}

Zacznijmy nasze poszukiwania od przytoczenia pięciu wypowiedzi o Duchu Paraklecie w oryginalnej wersji greckiej oraz w polskim filologicznym przekładzie (tekst grecki za Novum Testamentum Graece, ed. E. Nestle, K. Aland, wyd. 28, Stuttgart 2012, przekład polski własny):

\section{4, 16-17}

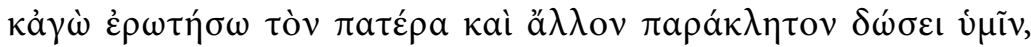

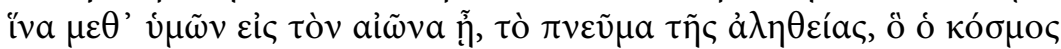

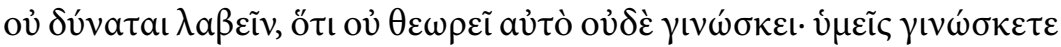

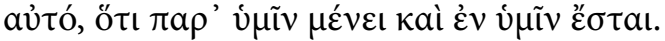

A Ja poprosze Ojca i innego Parakleta da wam, aby był $z$ wami na zawsze, Ducha Prawdy, którego świat nie może przyjąć, bo nie widzi Go ani nie zna. Wy znacie Go, bo u was pozostaje i $w$ was jest.

\section{$14,25-26$}

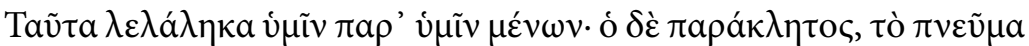

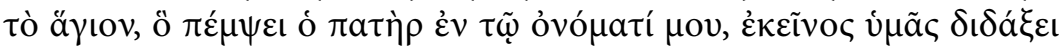

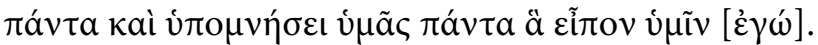

To wam powiedziałem, pozostając u was. Paraklet zaś, Duch Święty, którego pośle Ojciec w moim imieniu, ów nauczy was wszystkiego. I przypomni wam wszystko, co [Ja] wam powiedziałem.

\section{$15,25-26$}

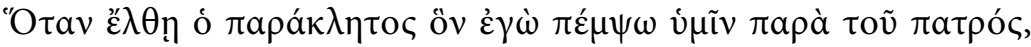

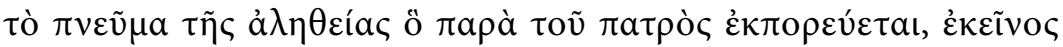

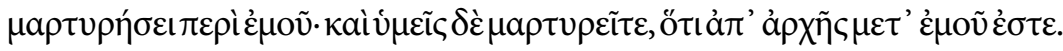


Gdy przyjdzie Paraklet, którego ja poślę wam od Ojca, Duch Prawdy, który od Ojca pochodzi, ów zaświadczy o mnie. Wy zaś świadczycie, bo od początku ze mna jesteście.

\section{$16,7-11$}

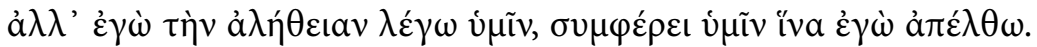

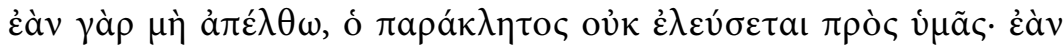

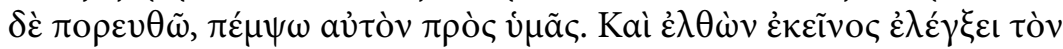

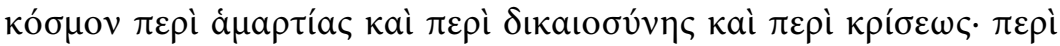

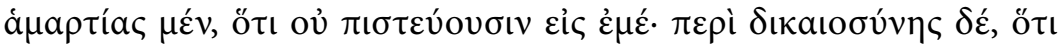

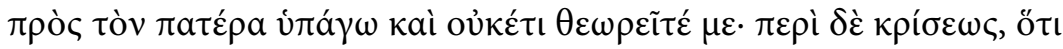

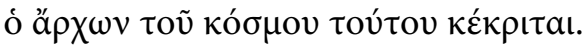

Lecz ja mówię wam prawdę, pożyteczne jest dla was, abym odszedł. Jeśli bowiem nie odejdę, Paraklet nie przyjdzie do was. Jeśli zaś pójdę, pośle Go do was. I przyszedtszy, ów przekona świat o grzechu, i o sprawiedliwości, i o sadzie. O grzechu, bo nie wierza we mnie. O sprawiedliwości zaś, bo do Ojca odchodzę i już nie widzicie mnie. O sądzie natomiast, bo władca tego świata jest osądzony.

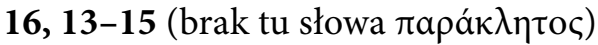

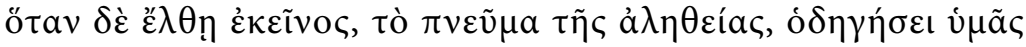

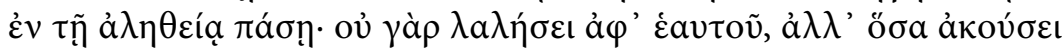

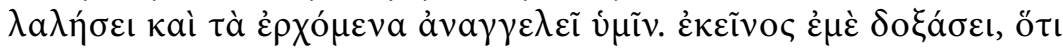

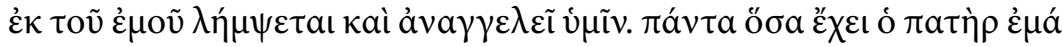

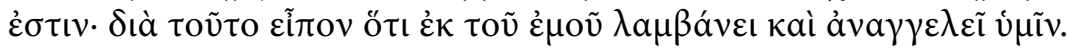

Kiedy zaś przyjdzie on, Duch Prawdy, poprowadzi was w całej prawdzie. Nie będzie bowiem mówił od siebie, ale ile usłyszy, mówił będzie, i oznajmi wam to, co ma nadejść. On mnie obdarzy chwała, bo z mojego weźmie i oznajmi wam. Wszystko, ile ma Ojciec, moje jest. Dlatego powiedziałem, że $z$ mojego bierze i oznajmi wam.

By jak najpełniej odczytać tożsamość i funkcję Ducha Parakleta w owych pięciu fragmentach mów pożegnalnych Jezusa, należy spojrzeć na tę postać szerzej w kontekście użycia słowa $\pi \alpha \rho a ́ k \lambda \eta \tau o \varsigma$ w literaturze i życiu codziennym starożytnej społeczności śródziemnomorskiej. 


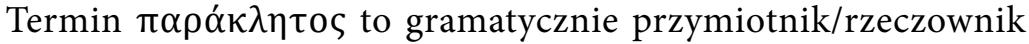

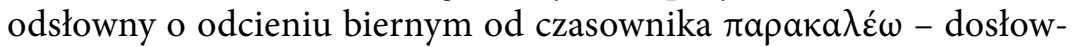
nie „przywołuję, wzywam”2. Najlepszy literalny przekład $\pi \alpha \rho a ́ k \lambda \eta \tau o \varsigma$ na język polski to „przywoływany/wzywany [na pomoc]”. W Nowym Testamencie jego użycie ogranicza się do czterech wystąpień w Jezusowych mowach pożegnalnych, gdzie odnosi się do Ducha Świętego

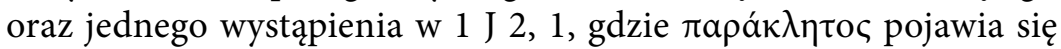

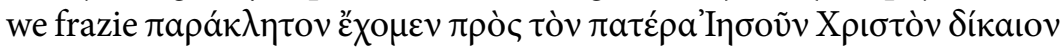
(„Parakleta mamy u Ojca, Jezusa Chrystusa sprawiedliwego”). Słowo $\pi \alpha \rho \alpha ́ \kappa \lambda \eta \tau o \varsigma$ jest tutaj użyte dla wyeksponowania pośredniczącej funkcji Jezusa Chrystusa w relacji pomiędzy wspólnotą chrześcijańską a Ojcem ${ }^{3}$. Jest tu mowa o pośrednictwie Chrystusa w wypraszaniu u Ojca przebaczenia grzechów: „Jeśliby nawet ktoś zgrzeszył, mamy Pośrednika u Ojca - Jezusa Chrystusa sprawiedliwego " $(1 \mathrm{~J} 2,1)$.

Prześledzimy krótko, jak ten termin był w owym czasie używany w kulturze i religiach świata śródziemnomorskiego. Co najmniej u trzech starożytnych greckich autorów - Demostenesa, Diogenesa

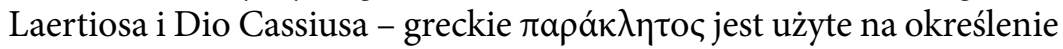
prawnego przedstawiciela, który broni czyjejś sprawy w sądzie - reprezentuje winnego przed sędzią, prosi w jego imieniu, doradza mu, jak należy się bronić, słowem: jest jego legalnym adwokatem ${ }^{5}$. Najczęściej jednak słowo $\pi \alpha \rho \alpha ́ \kappa \lambda \eta \tau o \varsigma$ było używane w życiu codziennym w sensie bardziej uniwersalnym - nieprawniczym - na określenie kogoś, kto prosi w czyjejś sprawie, oręduje. W takim znaczeniu termin ten używany jest także przez Filona Aleksandryjskiego, zwłaszcza

\footnotetext{
2 Zob. H.G. Liddell, R. Scott, A Greek-English Lexicon. A New Edition Revised and Augmented Throughout (BibleWorks 7 Version), 32560, Oxford 1996. Zob. też: J. Kuhl, Die Sendung Jesu und der Kirche nach dem Johannes-Evangelium, Siegburg 1967, s. 133-135.

3 Por. J. Kręcidło, Duch Święty i Jezus w Ewangelii świętego Jana. Funkcja pneumatologii w chrystologicznej strukturze czwartej Ewangelii, Częstochowa 2006, s. 241-242 (Series Biblica Paulina, 2).

4 W Biblii Tysiąclecia, wyd. 5, jest oddane w $1 \mathrm{~J}$ 2, 1 jako „Rzecznik”.

5 Zob. A Greek-English Lexicon of the New Testament. Being Grimm's Wilke's Clavis Novi Testamenti, trans. and revised by J.H. Thayer (BibleWorks 10 Version), 4001.
} 
gdy pisze o pośrednictwie boskiego Logosu. Wydaje się, że do tego znaczenia odwołuje się autor w $1 \mathrm{~J}$ 2, 1 (zob. powyżej), gdy pisze o pośrednicząco-wstawienniczej funkcji Jezusa, który oręduje u Boga za adresatami.

W Septuagincie nie znajdujemy ani jednego wystąpienia rzeczownika $\pi \alpha \rho \alpha ́ \kappa \lambda \eta \tau o \varsigma^{6}$. Występują jednak dwa razy terminy pokrewne wywo-

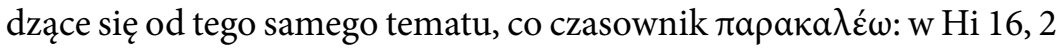

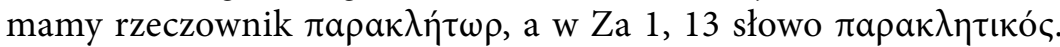
W obydwu tekstach są one tłumaczeniem słów hebrajskich wywodzących się od rdzenia נחם. Oddają zatem ideę pocieszania.

Należy także spojrzeć na tło religijne, które mogło mieć wpływ na kształtowanie się koncepcji Parakleta obecnej w czwartej Ewangelii. Egzegeci słusznie zauważają, że zadania, które ma pełnić wobec uczniów obiecany przez Jezusa Paraklet, są w jakiejś mierze zbieżne z tymi, które Duch Jahwe pełnił wobec starotestamentowych proro$\mathrm{ków}^{7}$. Są to przede wszystkim funkcja Parakleta jako interpretatora nauczania ziemskiego Jezusa $(14,16)$ oraz zadanie prowadzenia uczniów w całej prawdzie/doprowadzenia do prawdy (zob. 16, 13-15 oraz Ps 143, 10; Mdr 19, 17n; Iz 63, 9-14; Ag 2, 5).

Dużo światła na zrozumienie funkcji Ducha Parakleta w J 13 - 17 rzuca interpretacja owych wypowiedzi w świetle starotestamentowej idei pośrednictwa między Bogiem a ludźmi ${ }^{8}$. Jest to idea ważna dla teologii Starego Testamentu. Funkcję pośrednika i zarazem orędownika pełnili np. Abraham ( $\mathrm{Rdz} 18,23-33 ; 20,7.17)$, Mojżesz (Wj 32, 11-14. 32; 34, 8n; Lb 14, 13-19), Samuel (1 Sm 7, 8n; 12, 19. 23; 15, 11), Jeremiasz (Jr 14, 7n. 13. 19-22), Amos (Am 8, 46). Według czwartej Ewangelii to Jezus jest pośrednikiem par excellence pomiędzy Bogiem Ojcem a ludźmi (3, 11; 5, 31, 7, 7; 18, 36; 14, 16; 18, 37).

\footnotetext{
6 W manuskryptach A i $\Theta$ występuje w Hi w znaczeniu „pocieszyciel”.

7 Por. np. R.E. Brown, The Paraclete in the Fourth Gospel, „New Testament Studies” 13 (1967) issue 2, s. 120.

8 Więcej zob. S. Mowinckel, Die Vorstellung des Spätjudentums vom Heiligen Geist als Fürsprecher und der Johanneische Paraklet, „Zeitschrift für die neutestamentliche Wissenschaft und die Kunde der älteren Kirche" 32 (1932), s. 97-130.
} 
Paraklet zaś ma być zgodnie z obietnicą Jezusa kontynuatorem Jego misji pośrednictwa.

Pozostając nadal w strukturze myślenia o Paraklecie jako o pośredniku i kontynuatorze misji Jezusa na tle Starego Testamentu, można dostrzec pewną paralelę w sukcesjach: Jozuego jako kontynuatora misji Mojżesza, czy też Elizeusza jako kontynuatora i następcy prorockiej misji Eliasza (podobieństwo - następca rozpoczyna misję po odejściu poprzednika).

Funkcje Ducha Parakleta w mowach pożegnalnych Jezusa w J 13 - 17 bywają niekiedy zestawiane z zadaniami aniołów jako orędowników ${ }^{9}$. Pełnili oni funkcje sądownicze jako obrońcy (np. Hi 33, 23n) oraz funkcję wstawienniczą (np. Za 1, 12; 3, 1-10). W Księdze Daniela archanioł Michał ukazany jest jako opiekun ludu Bożego, walczący w jego obronie $\mathrm{z}$ innymi duchami $(10,13.21)$. Kolejne podobieństwo między funkcjami przypisywanymi Duchowi Parakletowi w Ewangelii Jana i aniołom w Dn to tłumaczenie/wyjaśnianie ludziom/uczniom Bożych znaków $(8,16-26 ; 9,21-27 ; 10,5-12)$. W księgach Starego Testamentu wielokrotnie podkreślana jest także ogólnie pośrednicząca rola aniołów (zob. np. Iz 43, 27; 2 Mch 3, 24-34; 11, 8-10; 15, 22n; Tb 12, 15).

Duże analogie można też dostrzec pomiędzy funkcjami Parakleta w czwartej Ewangelii a zadaniami maturgemana w judaizmie owego czasu. Osoba taka miała za zadanie czytać i komentować po aramejsku fragmenty Biblii hebrajskiej podczas liturgii synagogalnej. Maturgemanom przypisywano funkcje prorockie, nauczycielskie i interpretatorskie ${ }^{10}$.

Dobrego tła dla lepszego zrozumienia tożsamości i funkcji Parakleta w mowach pożegnalnych w Ewangelii Jana dostarcza również żydowska literatura apokaliptyczna. Najważniejszym pośrednikiem jest tu anioł Michał. Trzykrotnie w J 16, 13-16 działalność Parakleta

\footnotetext{
9 Na przykład: A. Jankowski, Paraklet, w: Egzegeza Ewangelii św. Jana. Kluczowe teksty i tematy teologiczne, red. F. Gryglewicz, Lublin 1992, s. 183-206.

10 Por. E. Franck, Revelation Taught. The Paraclete in the Gospel of John, Lund 1985, s. $132-140$.
} 


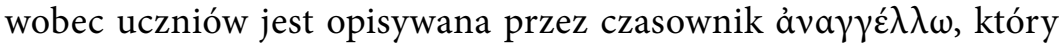
w literaturze apokaliptycznej określa działania aniołów jako pośredników w przekazie Bożego objawienia ludziom. Według Księgi Henocha 39, 5; 64, $5^{11}$, Testamentu Lewiego 6, 5 i Księgi Jubileuszów 30, 20 aniołowie jako pośrednicy pełnią wobec ludzi rolę opiekunów i funkcje sądownicze - zarówno jako obrońcy, jak i oskarżyciele. Księga Jubileuszów dostarcza kolejnej zbieżności - anioł opiekun jest tu ukazany jako ten, który ma za zadanie uczyć ludzi prawdy $(4,15 ; 32,21.26)$. W J 16, 13 zadaniem Ducha Parakleta jest doprowadzenie uczniów do całej prawdy.

Daleką analogię można dostrzec także pomiędzy Duchem Parakletem nazywanym Duchem Prawdy w Ewangelii Jana a רוּ רֶֶֶ w pismach z Qumran (1 QS 3, 24n). Zazwyczaj jednak pisma qumrańskie utożsamiają Ducha Prawdy z aniołem Michałem (1 QS 3, 20; CD 5, 18; 1 QM 17,6n).

Rudolf Bultmann twierdził, że idea i funkcja Parakleta zostały zaczerpnięte z gnozy mandejskiej ${ }^{12}$. Uczony ten utrzymywał, że w Ewangelii Jana mamy do czynienia $\mathrm{z}$ adaptacją mandejskiej koncepcji pomocnika - jawar, którego zadaniem było objawianie rzeczy przyszłych i prowadzenie ludzi do zbawienia. Zasadnicza różnica polega jednak na tym, że wedle gnozy mandejskiej istnieje wielu pośredników, a jawar jest jednym z nich, podczas gdy w czwartej Ewangelii to Jezus jest jedynym pośrednikiem, a rola Parakleta sprowadza się do kontynuacji Jego misji.

Niewątpliwie przedstawione tu w skrótowy sposób paralele najpierw z literaturą grecką, a potem Starym Testamentem i literaturą międzytestamentalną pozwalają szerzej zobaczyć możliwy semantyczny zakres zastosowanego w mowach pożegnalnych Jezusa terminu $\pi \alpha \rho a ́ k \lambda \eta \tau o \zeta$. $\mathrm{W}$ oparciu o przedstawione tu dane oraz analizę egzegetyczną owych pięciu wypowiedzi Jezusa o Duchu Paraklecie możemy pokusić się o określenie istotnych cech Jego tożsamości w J $13-17^{13}$ :

11 Zob. monografię: D. Iwański, Wstawiennictwo aniołów w Księdze Henocha (1 Hen), Torun 2011 (Scripta Theologica Thoruniensia, 15).

12 Zob. R. Bultmann, Das Evangelium des Johannes, Tübingen 1968, s. 439-440.

13 Por. J. Kręcidło, Duch Święty i Jezus w Ewangelii św. Jana..., dz. cyt., s. 209-310. 
1. Paraklet pochodzi od Ojca i Syna i jest kontynuatorem Ich dzieła na ziemi $(14,16.26 ; 15,26 ; 16,7)$.

2. Paraklet posłany jest do uczniów i jest obecny z nimi, pośród nich i w nich na zawsze po odejściu Jezusa do Ojca. Świat nie może Go przyjąć, widzieć ani znać (szczególnie 14, 17).

3. Najważniejszą funkcją Parakleta wobec uczniów jest uczenie ich wszystkiego i prowadzenie ich w całej prawdzie $(14,26 ; 16,13-$ 14), a także przekonanie świata o grzechu, sprawiedliwości i sądzie $(16,8-11)$.

4. Janowe przesłanie odnośnie do funkcji Parakleta można więc widzieć jako przypomnienie, nowe spojrzenie, umożliwienie zrozumienia i doświadczenia całości rzeczywistości Jezusa.

Zastosowanie narzędzi typowych dla antropologii kulturowej i socjologii pozwala jeszcze pełniej wniknąć w funkcje, które Jezus przypisuje Duchowi Parakletowi. Wyniki badań przeprowadzonych przy użyciu tych narzędzi referujemy w dalszej części niniejszego artykułu.

\section{Spojrzenie z punktu widzenia antropologii kulturowej}

Podejście antropologicznokulturowe w nurcie social science dostarcza narzędzi do metodologicznie odmiennego spojrzenia na funkcję Ducha Parakleta w czwartej Ewangelii. Otóż na postać Parakleta można spojrzeć w perspektywie modelu społecznego funkcjonowania patron klient/wasal ${ }^{14}$. Jest to system zależności społecznych pomiędzy ludźmi należącymi do odmiennych klas społecznych. Zależność ta dotyczyła na początku relacji rodzinnych, z czasem zaś zaczęła obejmować całość życia społecznego w świecie śródziemnomorskim ${ }^{15}$. System ten opierał się na wzajemnych prawach i zobowiązaniach. Patron

\footnotetext{
14 Mechanizmy funkcjonowania relacji patron - klient dobrze opisane są np. w zbiorowej monografii: Patron and Clients in Mediterranean Societies, ed. E. Gellner, J. Waterbury, London 1977.

15 Por. B.J. Malina, R.L. Rohrbaugh, Social-Science Commentary on the Gospel of John, Minneapolis 1998, s. 117-119.
} 
to człowiek z wyższej klasy społecznej, który wchodzi w relację wzajemnej zależności z wasalami z niższych warstw społecznych, roztaczając nad nimi opiekę w różnych życiowych sprawach i udzielając im ze swoich dóbr materialnych ${ }^{16}$. Klient natomiast w zamian ma być do dyspozycji patrona, przyjmując od niego różne zadania - usługi na jego rzecz. Najważniejszym jednak zadaniem wasali było wychwalanie wobec innych dobroci i hojności swojego patrona, co miało przydać mu chwały, sławy, honoru wobec innych członków społeczeństwa. W świecie, gdzie honor rozumiany jako prestiż społeczny był najwyższą wartością, liczba i status społeczny posiadanych wasali określały pozycję społeczną patrona i jego rodziny. Stąd też patroni rywalizowali między sobą, gdy idzie o liczbę i pochodzenie społeczne swoich wasali, gdyż wraz ze wzrostem liczby wasali o wyższym statusie społecznym wzrastał ich społeczny prestiż. Całe społeczeństwo śródziemnomorskie było w ten sposób zhierarchizowane - od cesarza po niewolnika.

Specjalną odmianą patronatu był tzw. brokerage, który pozwalał wchodzić w relacje patron - klient osobom pochodzącym z odległych warstw społecznych ${ }^{17}$. Przypomnijmy, że relacja patron - klient była zarezerwowana tylko dla ludzi z sąsiednich klas społecznych. Jeżeli zaś pojedynczy ludzie lub większe grupy społeczne pragnęły prosić o patronat kogoś $\mathrm{z}$ wyższych warstw społecznych, należało poszukać tzw. brokera - człowieka z wyższej od nich klasy społecznej, który pośredniczyłby w nawiązaniu i realizacji relacji patron - klient pomiędzy odległymi warstwami społecznymi. Bibliści nurtu social science patrzą w tej perspektywie na postać Jezusa w Nowym Testamencie zwłaszcza w Ewangelii wg św. Jana, gdzie jest On wyraźnie ukazany jako Pośrednik pomiędzy Ojcem a uczniami ${ }^{18}$. Jest tym, poprzez kogo

\footnotetext{
16 Szerzej w: N.F. Santos, Family, Patronage, and Social Context. Narrative Reversals in the Gospel of Mark, „Scripture and Interpretation” 2 (2008), s. 200-224.

17 Więcej na ten temat: J. Kręcidło, Honor $i$ wstyd $w$ interpretacji Ewangelii. Szkice z egzegezy antropologicznokulturowej, Warszawa 2013, s. 42-43 (Lingua Sacra. Monografie, 1).

18 Zob. monografię na ten temat: T. Gates Brown, Spirit in the Writings of John: Johannine Pneumatology in Social-Scientific Perspective, London 2004.
} 
poznają Ojca i mogą w Nim nawiązywać z Nim relację. Jedną z głównych strategii pragmatycznych autora czwartej Ewangelii jest ukazanie Jezusa jako Pośrednika Ojca w dziele objawienia Go uczniom i światu oraz zbawienia świata.

Czy ta wiedza może w jakiś sposób przyczynić się do lepszego zrozumienia tożsamości i funkcji Ducha Parakleta obiecanego przez Jezusa w mowach pożegnalnych J 13 - 17? Otóż Jezus w swoich pięciu

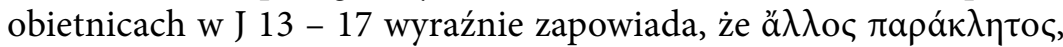
Duch Święty, którego pośle uczniom od Ojca, będzie dla nich Jego reprezentantem, Jego uobecnieniem. Będzie zatem pełnił wobec nich funkcje, które dotychczas pełnił sam Jezus. W Jego zastępstwie będzie Pośrednikiem pomiędzy Ojcem i Nim samym - gdy powróci już do Ojca - a uczniami. Uczniowie zaś mają pełnić misję pośredników pomiędzy Bogiem - Jezusem uwielbionym - Duchem Parakletem a światem.

Kategoria brokera - pośrednika, odzwierciedlająca mechanizmy funkcjonowania społecznego w kulturze śródziemnomorskiej czasów Jezusa i rodzącego się Kościoła, może stać się pomocna do pełniejszego zrozumienia pośredniczącej funkcji Jezusa i Ducha Parakleta.

\section{Spojrzenie z socjologicznego punktu widzenia - modele funkcjonowania grup}

W ujęciu socjologicznym patrzymy na tożsamość i funkcję Ducha Parakleta, starając się uwzględnić kulturowy kontekst wspólnoty, która przedstawiła nauczanie Jezusa w taki sposób, by wpisać weń swoje własne doświadczenie wiary. Tekst Ewangelii Jana oraz listów Jana pozwala nam dzięki zobiektywizowanym modelom do pewnego stopnia odtworzyć tożsamość wspólnoty Janowej i następnie wnioskować o tym, jak postrzegała ona tożsamość i aktywność Ducha Parakleta.

Do spojrzenia socjologicznego na postać Ducha Parakleta w mowach pożegnalnych Jezusa w J 13 - 17 zastosujemy dwa modele. Pierwszy z nich to statyczny model Bryana Wilsona ukazujący mechanizmy funkcjonowania grup, drugi zaś to dynamiczny model transformacji 
zachodzących w grupach, zaproponowany przez brytyjsko-amerykańską antropolog Mary Douglas. Chcemy zastosować te modele do zbadania tego, jak wspólnota Janowa postrzegała tożsamość i funkcję Ducha Parakleta.

Bryan Wilson zaproponował podział grup religijnych na siedem typów w zależności od przejawianych przez nie zachowań w odniesieniu do świata zewnętrznego oraz członków grupy do siebie nawzajem ${ }^{19}$. W zaproponowanej przez niego typologii znajdują się następujące typy grup: konwersjonistyczna, rewolucjonistyczna, introwersjonistyczna, gnostycko-manipulacjonistyczna, taumaturgiczna, reformistyczna i utopijna ${ }^{20}$. Nie miejsce tutaj na szczegółową prezentację charakterystycznych cech każdej z nich. Wydaje się, że wspólnota Janowa, której charakterystyczne cechy można określić na podstawie analizy pozostawionych przez nią pism - Ewangelii wg św. Jana i trzech listów Jana, najbardziej odpowiada cechom grupy introwersjonistycznej oraz w jakimś stopniu konwersjonistycznej.

Członkowie grupy introwersjonistycznej uważają, że świat jest zły i aby osiągnąć zbawienie, należy wycofać się z udziału w nim ${ }^{21}$. Nie można świata po prostu stopniowo zreformować, lecz aby móc żyć wartościami, w które wspólnota wierzy, należy się ze świata wyalienować. Bóg objawia członkom grupy prawdę, która jest niedostępna dla świata zewnętrznego. Grupa nie dąży do zdobywania jak największej liczby różnorodnych doświadczeń duchowych, lecz do pogłębiania tych, które członkowie grupy uważają za najistotniejsze. Członkowie grupy są przekonani o swoim szczególnym wybraniu i nie są nastawieni na nawracanie innych poprzez działalność misyjną. Doceniają

\footnotetext{
19 Zob. B.R. Wilson, A Typology of Sects, w: Sociology of Religion, ed. R. Robertson, Baltimore 1969, s. 361-383. Zob. też: B.R. Wilson, An Analysis of Sect Development, "American Sociological Review" 24 (1959) no.1, s. 3-15; B.R. Wilson, Religious Sects. A Sociological Study, London 1970; B.R. Wilson, Sects and Society, London 1978.

20 Bardziej szczegółowe omówienie owych typów grup oraz aplikacja modelu Wilsona do Listu Jakuba znajduje się w: D. Muszytowska, Etos chrześcijańskiej wspólnoty. Socjoretoryka Listu Jakuba, Warszawa 2016, s. 202-314.

${ }_{21}$ Zob. też: J.A. Draper, The Sociological Function of the Spirit/Paraclete in the Farewell Discourses in the Fourth Gospel, „Neotestamentica” 26 (1992) issue 1, s. 13-29.
} 
jednak rolę świadectwa. W perspektywie zasad funkcjonowania grupy introwersjonistycznej można zrozumieć lepiej funkcje, które Jezus przypisuje Duchowi Parakletowi wobec członków wspólnoty uczniów w mowach pożegnalnych. Paraklet ma być dla nich objawicielem, nauczycielem i świadkiem Prawdy, którą jest Jezus. Zagadnienie to rozwiniemy szerzej nieco później.

Wspólnota Janowa, według tego jako ukazuje siebie w Ewangelii Jana i w listach Janowych, nosi w sobie także pewne cechy grupy konwersjonistycznej. Członkowie takich grup religijnych uważają, że świat jest z gruntu zepsuty i nie można go uzdrowić poprzez reformowanie struktur społecznych i politycznych. Reforma świata możliwa jest jedynie dzięki moralnej i duchowej odnowie człowieka, która dokonuje się poprzez osobisty kontakt $\mathrm{z}$ rzeczywistością transcendentną. Działalność misyjna grupy zmierza do odnowy duchowej świata, a nie do reformy struktur społecznych. Duch Paraklet ma z jednej strony stymulować kontakt wspólnoty Kościoła Janowego z rzeczywistością transcendentną, z drugiej zaś strony pomagać budować tożsamość owej grupy ludzi dystansujących się wobec wrogiego świata i dążących do wewnętrznej duchowej odnowy.

Zanim głębiej spojrzymy na postać Ducha Parakleta w pięciu wypowiedziach Jezusa w mowach pożegnalnych z perspektywy socjologicznej, przedstawimy podstawowe etapy rozwoju wspólnoty Janowej w perspektywie modelu zaproponowanego przez Mary Douglas ${ }^{22}$. W odróżnieniu od przedstawionego powyżej modelu Bryana Wilsona, który klasyfikował grupy religijne w aspekcie synchronicznym, model zaproponowany przez Mary Douglas ukazuje w sposób diachroniczny węzłowe etapy rozwoju każdej ludzkiej zbiorowości uniezależniającej się od innej i stopniowo kształtującej swoją własną tożsamość. Procesy formułowania się ludzkich zbiorowości można zaobserwować, stosując

\footnotetext{
22 Zob. M. Douglas, Natural Symbols. Exploration in Cosmology, London 1996, zwłaszcza s. 57-71. By lepiej zrozumieć antropologiczną koncepcję M. Douglas, warto skonsultować także: M. Douglas, Purity and Danger. An Analysis of the Concept of Pollution and Taboo, London 1966; M. Douglas, Risk and Blame. Essays in Cultural Theory, London 1994.
} 
jako kryterium dwie zmienne, mianowicie group, tzn. grupa, oraz grid, czyli sieć/kratownica. Zmienna group analizuje poziom zintegrowania badanej grupy z szerszą grupą społeczną, stanowiącą dla niej matrycę $^{23}$. Jeżeli członkowie są mocno związani z grupą matką, to ma ona charakter kolektywistyczny, jeżeli zaś nie, to indywidualistyczny. Zmienna grid analizuje natomiast stopień zaangażowania członków grupy w wartości wyznawane przez członków szerszej grupy społecznej oraz dzielenie z nią wspólnych egzystencjalnych doświadczeń.

Przykładając te proste zmienne do procesu ewoluowania wspólnoty Janowej, łatwo zauważyć, że na początkowym etapie osoby, które uwierzyły w Jezusa jako Mesjasza, przynależały do judaizmu synagogalnego, tzn. do swoich własnych lokalnych wspólnot, z którymi były mocno kolektywistycznie zintegrowane (mocna grupa) oraz dzieliły z nimi wspólne tradycje i wierzenia (wysoki grid) ${ }^{24}$. Wiara w Jezusa jako Mesjasza powodowała $\mathrm{w}$ nich pierwotnie pragnienie zreformowania swojej własnej wspólnoty matki - judaizmu synagogalnego. Wyznawane wartości, związane $\mathrm{z}$ osobą Jezusa jako Mesjasza, integrowały owych ludzi coraz bardziej ze sobą i stały coraz bardziej w sprzeczności z wartościami wyznawanymi przez grupę matkę, co osłabiało ich sieć powiązań z judaizmem synagogalnym (coraz niższy grid z grupą matką). W ten sposób grupa coraz bardziej zdobywa swoją własną tożsamość - coraz mocniejszy czynnik group (poziom zintegrowania członków wspólnoty, która coraz mocniej integruje się wewnętrznie) i coraz wyższy grid (wartości, które wyznają i sposób działania coraz bardziej oddalają ich od grupy matki). Ludzie ci przynależą jeszcze instytucjonalnie do judaizmu synagogalnego, ale coraz bardziej zastępują tradycje żydowskie przez swoje własne, związane z osobą Jezusa Mesjasza. W miejsce, które w judaizmie synagogalnym zajmowała Tora,

\footnotetext{
23 Zob. diagram zależności między group and grid w: M. Douglas, Natural Symbols. Exploration in Cosmology, dz. cyt., s. 64.

24 Zob. rezultaty szczegółowych analiz historii wspólnoty Janowej w perspektywie modelu M. Douglas w: J. Kręcidło, Nowe życie uczniów Jezusa. J 21 jako owoc eklezjologicznej relektury J 1 - 20 we wspólnocie Umiłowanego Ucznia, Warszawa 2008, s. 322-328 (Rozprawy i Studia Biblijne, 33).
} 
pojawia się kult Jezusa jako Mesjasza. Doprowadziło to do krytycznego momentu, gdy grupa ta dzieliła już z judaizmem synagogalnym tak mało wspólnych wartości, a jej poczucie zintegrowania z grupą matką było tak słabe, że skutkowało to formalnym usunięciem jej z niej birkat hamminim. Spowodowało to kryzys w owej konstytuującej się wspólnocie Kościoła Janowego. Niektórzy zdecydowali się wrócić na łono grupy matki, inni wybrali drogę w kierunku gnozy. Natomiast ci, którzy pozostali we wspólnocie Umiłowanego Ucznia, jeszcze mocniej zintegrowali się wewnętrznie - mocny wskaźnik group i wysoki grid. Jest to etap umacniania własnej tożsamości, któremu towarzyszy poczucie wyalienowania ze środowiska judaizmu synagogalnego i ze świata. Po okresie wewnętrznego scalania rodzi się w grupie Kościoła Janowego potrzeba integracji z tzw. wielkim Kościołem, uznającym Piotra za swego przywódcę. Proces ten znajduje odzwierciedlenie w 21 rozdziale czwartej Ewangelii ${ }^{25}$.

Spojrzawszy na wspólnotę Janową w świetle owych dwóch modeli socjologicznych, zapytajmy teraz o tożsamość i funkcję Ducha Parakleta w tej wspólnocie i szerzej w Kościele wszystkich czasów według tego, jak ujmuje to Jezus w pięciu obietnicach w mowach pożegnalnych.

Sam kontekst mów pożegnalnych sygnalizuje dwie zasadnicze wartości, którymi ma żyć wspólnota po odejściu Jezusa do Ojca. Pierwszy kontekst (na poziomie tekstu Ewangelii wg św. Jana) wynika z faktu, że uczniowie są zamkniętą grupą społeczną, znajdującą się w zamkniętej przestrzeni wieczernika. Jest tu idea oddzielenia od świata - pomiędzy wspólnotą a światem jest nieprzekraczalna dla niego granica ${ }^{26}$. To Jezus decyduje, kto jest z Nim w owej przestrzeni wspólnoty. Jest to wyraźnie grupa introwersjonistyczna według przedstawionej powyżej klasyfikacji Wilsona. Drugi istotny element to fakt, że podstawową wartością, którą ma żyć wspólnota, jest miłość - całe opowiadanie J 13 - 17 rozpoczyna się od Jezusowego gestu/rytuału obmycia

\footnotetext{
25 Por. J. Kręcidło, Nowe życie uczniów Jezusa..., dz. cyt., s. 345-368.

26 Różne odcienie koncepcji granic w antropologii dobrze pokazują np. M. Lamont, V. Molnár, The Study of Boundaries in the Social Sciences, „Annual Review of Sociology" 28 (2002), s. 167-195.
} 
nóg uczniom, będącego wyrazem Jego najwyższej miłości do nich ${ }^{27}$. Wspólnota uczniów ma pielęgnować przykazanie wzajemnej miłości wzorowanej na Jego relacji z Ojcem.

Spójrzmy teraz kolejno na obietnice Jezusa w J 13 - 17, dokonując ich analizy w perspektywie pytania: Jaka ma być rola Ducha Parakleta w konstytuowaniu i przeżywaniu swojej tożsamości przez wspólnotę uczniów?

\section{$14,16-17$}

W pierwszej obietnicy 14,16-17 Duch Święty jest nazwany å $\lambda \lambda$ oc

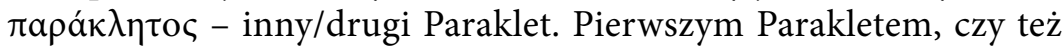
Parakletem par excellence, jest więc sam Jezus ${ }^{28}$. Zatem Duch Paraklet, posłany przez Ojca, ma być Jego uobecnieniem, ma pełnić we wspólnocie role, jakie pełnił w niej Jezus. Ma być niejako alter Jesus. Ma być z członkami wspólnoty na zawsze jako Duch Prawdy, a Prawdą w Ewangelii Jana jest sam Jezus ${ }^{29}$. Natomiast świat, czyli wszyscy, którzy są poza wyznaczoną granicą wspólnoty, nie są w stanie ani Ducha Parakleta rozpoznać, ani tym bardziej znać Go, tzn. nawiązać z Nim relację. Widać tu wyraźnie, że Duch Paraklet ma za zadanie nieustannie stymulować członków owej introwersjonistycznej grupy i upewniać ich o prawdziwości Jezusa wobec wrogiego świata. Ma On im zrekompensować fizyczną nieobecność Jezusa. Z punktu widzenia dynamicznego modelu Douglas odpowiada to samoświadomości grupy Kościoła Janowego, która została już poza nawiasem judaizmu synagogalnego i zmaga się z kształtowaniem swojej własnej tożsamości, pozycjonując się wobec innych.

\footnotetext{
27 Por. B.J. Malina, R.L. Rohrbaugh, Social-Science Commentary on the Gospel of John, Minneapolis 1998, s. 219.

28 Zob. szerzej: R. Schnackenburg, Das Johannesevangelium, Bd. 4, Freiburg 1971, s. 46 (Herders theologischer Kommentar); H. Witczyk, Paraklet Duchem Nowego Przymierza (J 14, 15-17), „Roczniki Teologiczne” 46 (1999) nr 1, s. 77-91.

29 Więcej na ten temat zob. I. de la Potterie, La Vérité dans Saint Jean, t. 1-2, Rome 1977 (Analecta Biblica); U. Schnelle, Johannes als Geisttheologe, „Novum Testamentum" 40 (1998) fasc. 1, s. 17-31 (zwłaszcza s. 19).
} 


\section{$14,25-26$}

Owej introwersjonistycznej grupie brakuje pewności siebie, gdyż zmaga się w walce o zachowanie wiary w Jezusa jako jedynej Prawdy. Podobnie jak wielokrotnie w Ewangelii Jana oraz w pierwszej obietnicy, Jezus powołuje się tutaj na autorytet Ojca. To On autoryzował całą Jego ziemską działalność. To On również ma posłać wspólnocie uczniów Ducha Parakleta. Ma to jednak zrobić w imieniu Jezusa. Zadaniem Parakleta ma być duchowe i intelektualne umacnianie uczniów. Ma im przypominać wszystko, co Jezus im powiedział i wszystkiego ich uczyć ${ }^{30}$. Wspólnota nie ma mieć ziemskiego autorytetu, który miałby nią kierować i wyznaczać konkretne reguły codziennego postępowania jako realizacji przykazania miłości. Jedynym autorytetem ma być dla niej zawsze Jezus, komunikowany wspólnocie uczniów przez Ducha Parakleta, którego zadaniem jest „przypominanie” wszystkiego, co On powiedział ${ }^{31}$. Duch Święty Paraklet nie ma zatem wprowadzać do wspólnoty nowych wartości, dostosowujących nauczanie Jezusa do ducha czasów. Jego zadaniem jest uobecnianie Jezusa we wspólnocie - Jego osoby i nauki. Nie ma tu mowy o jakiejkolwiek modernizacji czy też aggiornamento.

\section{$15,25-26$}

Obietnica ta kontynuuje i wyjaśnia treści zawarte $\mathrm{w}$ dwóch poprzednich. Inaczej jednak niż w 14, 16-17 i 14, 25-26, Jezus stwierdza, że to On sam pośle uczniom Parakleta od Ojca. Nie ma tutaj sprzeczności, gdyż Jezus wielokrotnie podkreśla w Ewangelii swoją jedność z Ojcem najmocniej wybrzmiewa to w stwierdzeniu: „Ja i Ojciec jedno jesteśmy” $(\mathrm{J} 10,30)^{32}$. Ojciec i Syn są jedno także w działaniu wobec wspólnoty uczniów. Zadaniem Ducha Parakleta wobec uczniów (ale nie wobec

\footnotetext{
30 Por. A.M. Kothgasser, Die Lehr-, Bezeugungs-, und Einführungsfunktion des johanneischen Geist-Parakleten gegenüber der Christus-Offenbarung, „Salesianum” 33 (1971), s. 590nn; A. Jankowski, Zarys pneumatologii Nowego Testamentu, Kraków 1982, s. 41;

A. Paciorek, Ewangelia umiłowanego ucznia, Lublin 2000, s. 366.

31 Por. I. de la Potterie, Le Paraclet..., dz. cyt., s. 90.

32 Por. I. de la Poterie, Le Paraclet..., dz. cyt., s. 98.
} 
świata, sic!) będzie świadczenie o Jezusie (czasownik $\mu \alpha \rho \tau$ $\left.\varepsilon^{2} \omega\right)^{33}$. Oznacza to, że uczniowie będą nieustanie potrzebowali umacniania w wierze poprzez świadectwo Parakleta o Jezusie ${ }^{34}$. Oni również mają dawać świadectwo o Nim wobec siebie. Świadectwo to dają poprzez fakt przynależności do wspólnoty - bycia z Jezusem od początku. Są to wyraźne cechy grupy introwersjonistycznej, która nie jest nastawiona na działalność misyjną, lecz na przeżywanie obecności Jezusa w wspólnocie, życie wartościami, które są tego pochodną, i umacnianie wzajemnych więzi poprzez trwanie we wspólnocie i dawanie w ten sposób sobie nawzajem świadectwa o tym, że Jezus jest Prawdą.

\section{$16,7-11$}

Z punktu widzenia wspólnoty, która przekazała te słowa Jezusowej obietnicy, mogą one odzwierciedlać dylematy, czy też kryzysy wiary, przeżywane przez członków grupy introwersjonistycznej, związane ze skandalem krzyża oraz faktem, że nie było już z nimi historycznego Jezusa, który stanowił sens ich życia. Widać wyraźnie, że wspólnota zmaga się z konstytuowaniem swojej własnej tożsamości, bywa zagubiona odnośnie do pewnych podstawowych prawd: grzech, sprawiedliwość, sąd. W odpowiedzi na to padają słowa Jezusa, które mają ich przekonać, że Jego odejście do Ojca było dla nich pożyteczne, gdyż dzięki temu może/mógł być im dany Duch Paraklet, który jest/ będzie z nimi już na zawsze i będzie aktywnie działał jako Leader ich wspólnoty w imię i w zastępstwie Jezusa. Jezus przekonuje, że wartości, które wyznają, są prawdziwe, i że Paraklet zatroszczy się, by przekonać świat - czyli wszystkich, którzy są poza granicami introwersjonistycznej wspólnoty - że grupa ta ma rację odnośnie do prawdy o Jezusie, w kwestii grzechu, sprawiedliwości i sądu ${ }^{35}$. To działanie

\footnotetext{
33 Por. G. Johnston, The Spirit-Paraclete in the Gospel of John, Cambridge 1970, s. 135n; U. Schnelle, Johannes als Geisttheologe..., dz. cyt., s. $21 \mathrm{n}$.

34 Szerzej zob. J. Kręcidło, Duch Święty i Jezus w Ewangelii św. Jana..., dz. cyt., s. $301 \mathrm{n}$. 35 Por. H.S. Benjamin, Pneuma in John and Paul. A Comparative Study of the Term with Particular Reference to the Holy Spirit, „Biblical Theology Bulletin” 6 (1976) issue 1, s. 34 .
} 
Parakleta ma być skuteczne ${ }^{36}$, tzn. ma przekonać innych do wiary w Jezusa, przekonać o tym, że było czymś sprawiedliwym i potrzebnym, by odszedł do Ojca, oraz o tym, że zło zostanie ostatecznie pokonane i osądzone ${ }^{37}$. Z perspektywy modelu Douglas wypowiedź ta może odzwierciedlać moment kryzysu we wspólnocie, kiedy to wyznawcy Jezusa Mesjasza zostali wykluczeni z judaizmu synagogalnego, a wielu zdecydowało się na wyrzeczenie się tych wartości i powrót do wspólnoty matki lub na drogę w kierunku gnozy. Nauka o Paraklecie ma ich zapewnić, że są na dobrej drodze i że prawda, którą wyznają, ostatecznie zatryumfuje. Paraklet ma być dla nich niezawodnym przewodnikiem na tej drodze.

\section{$16,13-15$}

Obietnica ta jest kontynuacją poprzedniej, a jednocześnie rekapitulacją całej argumentacji odnośnie do tożsamości oraz roli Ducha Świętego we wspólnocie Kościoła Janowego. Paraklet ma prowadzić wspólnotę w całej Prawdzie, którą jest sam Jezus ${ }^{38}$. Jest to nie tylko prowadzenie do pogłębienia wiary w Jezusa, lecz prowadzenie w Nim samym. W obietnicy tej widać staranie, by członkowie wspólnoty nie stali się twórczymi i samodzielnymi interpretatorami osoby i nauki Jezusa. Paraklet nie ma mówić od siebie - tzn. nie ma samodzielnie interpretować Jego Osoby i pozostawionej przez Niego nauki, lecz ma mówić jedynie to, co usłyszy od Jezusa ${ }^{39}$. Ma być komunikatorem,

\footnotetext{
36 Por. J. Szlaga, Historiozbawcza misja Ducha Świętego wedtug J 16, 8-11, w: Duch Święty - Duch Boży (Materiały pomocnicze do wykładów z biblistyki, 7, red. S. Łach, M. Filipiak), Lublin 1984, s. 106.

37 Por. I. de la Potterie, Le Paraclet..., dz. cyt., s. 103.

38 Więcej na ten temat zob. B. Olsson, Structure and Meaning in the Fourth Gospel. A Text-Linguistic Analysis of John 2:1-11 and 4:1-42, Lund 1974, s. 270; F. Genuyt, Le passage de Jésus et la venue du Paraclet. Analyse sémiotique du ch. 16 de l'Evangile de Jean, „Sémiotique et Bible” 34 (1984), s. 1-14.

39 Zob. też: A.M. Kothgasser, Die Lehr-, Bezeugungs-, und Einführungsfunktion des johanneischen Geist-Parakleten gegenüber der Christus-Offenbarung..., dz. cyt., s. 19-27; G. Ferraro, Lo Spirito della Verità nel Vangelo di Giovanni, „Parola, Spirito e Vita” 4 (1981), s. 138.
} 
a nie interpretatorem prawdy o $\mathrm{Nim}^{40}$. Nauczanie Parakleta o Jezusie ma przydawać Mu chwały, tzn. uświadamiać członkom wspólnoty Jego Boskość i jedyność, poprzez nieustanne przypominanie im prawdy, że Syn stanowi jedno z Bogiem Ojcem.

\section{Podsumowanie}

W niniejszym artykule postawiliśmy sobie zadanie spojrzenia na postać Ducha Parakleta w mowach pożegnalnych Jezusa w Ewangelii wg św. Jana (rozdz. 13-17) w perspektywie socjologicznej i antroplogicznokulturowej. Realizację tego zadania poprzedziliśmy ukazaniem wyników badań współczesnej egzegezy historyczno-krytycznej odnośnie do tożsamości i funkcji Parakleta w czwartej Ewangelii. W aspekcie antropologicznokulturowym ukazaliśmy postać Ducha Parakleta jako Brokera/Pośrednika, który ma być reprezentantem i kontynuatorem misji Jezusa - Pośrednika par excellence po Jego powrocie do Ojca. Posługując się socjologicznymi modelami Bryana Wilsona i Mary Douglas, przeanalizowaliśmy pięć wypowiedzi Jezusa w J 13 - 17, aby ukazać aktywność Ducha Parakleta w introwersjonistycznej wspólnocie Kościoła Janowego.

\section{Bibliografia}

A Greek-English Lexicon of the New Testament. Being Grimm's Wilke's Clavis Novi Testamenti, trans. and revised by J.H. Thayer (BibleWorks 10 electronic version), 4001.

Benjamin H.S., Pneuma in John and Paul. A Comparative Study of the Term with Particular Reference to the Holy Spirit, „Biblical Theology Bulletin” 6 (1976) issue 1, s. 27-48.

40 Por. J. Zumstein, Le processus de relecture dans la littérature johannique, „Etudes Théologiques et Religieuses" 78 (1998) núm. 2, s. 175. 
Brown R.E., The Paraclete in the Fourth Gospel, „New Testament Studies” 13 (1967) issue 2, s. 113-132.

Bultmann R., Das Evangelium des Johannes, Tübingen 1968.

de la Potterie I., La Vérité dans Saint Jean, t. 1-2, Rome 1977 (Analecta Biblica). de la Potterie I., Le Paraclet, w: I. de la Potterie, La vie selon l'Esprit, Paris 1965. Douglas M., Natural Symbols. Exploration in Cosmology, London 1996.

Douglas M., Purity and Danger. An Analysis of the Concept of Pollution and Taboo, London 1966.

Douglas M., Risk and Blame. Essays in Cultural Theory, London 1994.

Draper J.A., The Sociological Function of the Spirit/Paraclete in the Farewell Discourses in the Fourth Gospel, „Neotestamentica” 26 (1992) issue 1, s. 13-29.

Ferraro G., Lo Spirito della Verità nel Vangelo di Giovanni, „Parola, Spirito e Vita” 4 (1981), s. 130-141.

Franck E., Revelation Taught. The Paraclete in the Gospel of John, Lund 1985.

Gates Brown T., Spirit in the Writings of John: Johannine Pneumatology in Social-Scientific Perspective, London 2004.

Genuyt F., Le passage de Jésus et la venue du Paraclet. Analyse sémiotique du ch. 16 de l'Evangile de Jean, „Sémiotique et Bible” 34 (1984), s. 1-14.

Iwański D., Wstawiennictwo aniołów w Księdze Henocha (1 Hen), Toruń 2011 (Scripta Theologica Thoruniensia, 15).

Jankowski A., Paraklet, w: Egzegeza Ewangelii św. Jana. Kluczowe teksty i tematy teologiczne, red. F. Gryglewicz, Lublin 1992, s. 183-206.

Jankowski A., Zarys pneumatologii Nowego Testamentu, Kraków 1982.

Johnston G., The Spirit-Paraclete in the Gospel of John, Cambridge 1970.

Kothgasser A.M., Die Lehr-, Bezeugungs-, und Einführungsfunktion des johanneischen Geist-Parakleten gegenüber der Christus-Offenbarung, „Salesianum” 33 (1971), s. 557-598.

Kręcidło J., Duch Święty i Jezus w Ewangelii świętego Jana. Funkcja pneumatologii w chrystologicznej strukturze czwartej Ewangelii, Częstochowa 2006 (Series Biblica Paulina, 2).

Kręcidło J., Honor i wstyd w interpretacji Ewangelii. Szkice z egzegezy antropologicznokulturowej, Warszawa 2013 (Lingua Sacra. Monografie, 1).

Kręcidło J., Nowe życie uczniów Jezusa. J 21 jako owoc eklezjologicznej relektury J 1 - 20 we wspólnocie Umiłowanego Ucznia, Warszawa 2008 (Rozprawy i Studia Biblijne, 33). 
Kuhl J., Die Sendung Jesu und der Kirche nach dem Johannes-Evangelium, Siegburg 1967.

Lamont M., Molnár V., The Study of Boundaries in the Social Sciences, „Annual Review of Sociology" 28 (2002), s. 167-195.

Liddell H.G., Scott R., A Greek-English Lexicon. A New Edition Revised and Augmented Throughout, Oxford 1996 (BibleWorks 7 Version, 32560).

Malina B.J., Rohrbaugh R.L., Social-Science Commentary on the Gospel of John, Minneapolis 1998.

Mowinckel S., Die Vorstellung des Spätjudentums vom Heiligen Geist als Fürsprecher und der Johanneische Paraklet, „Zeitschrift für die neutestaamentliche Wissenschaft und die Kunde der ältern Kirche” 32 (1932), s. 97-130.

Muszytowska D., Etos chrześcijańskiej wspólnoty. Socjoretoryka Listu Jakuba, Warszawa 2016.

Novum Testamentum Graece, ed. E. Nestle, K. Aland, wyd. 28, Stuttgart 2012.

Olsson B., Structure and Meaning in the Fourth Gospel. A Text-Linguistic Analysis of John 2:1-11 and 4:1-42, Lund 1974.

Paciorek A., Ewangelia umiłowanego ucznia, Lublin 2000.

Patron and Clients in Mediterranean Societies, ed. E. Gellner, J. Waterbury, London 1977.

Santos N.F., Family, Patronage, and Social Context. Narrative Reversals in the Gospel of Mark, „Scripture and Interpretation” 2-3 (2008), s. 200-224.

Schnackenburg R., Das Johannesevangelium, t. 4, Freiburg 1971 (Herders theologischer Kommentar).

Schnelle U., Johannes als Geisttheologe, „Novum Testamentum” 40 (1998) fasc. 1, s. $17-31$.

Szlaga J., Historiozbawcza misja Ducha Świętego według J 16, 8-11, w: w: Duch Święty - Duch Boży (Materiały pomocnicze do wykładów z biblistyki, 7, red. S. Łach, M. Filipiak), Lublin 1984.

Wilson B.R., A Typology of Sects, w: Sociology of Religion, ed. R. Robertson, Baltimore 1969, s. 361-383.

Wilson B.R., An Analysis of Sect Development, "American Sociological Review” 24 (1959) no. 1, s. 3-15.

Wilson B.R., Religious Sects. A Sociological Study, London 1970.

Wilson B.R., Sects and Society, London 1978. 
Witczyk H., Paraklet Duchem Nowego Przymierza (J 14, 15-17), „Roczniki Teologiczne" 46 (1999) nr 1, s. 77-91.

Zumstein J., Le processus de relecture dans la littérature johannique, „Etudes Théologiques et Religieuses” 78 (1998) núm. 2, s. 161-176.

\section{Streszczenie}

Artykuł ma na celu analizę postaci Ducha Parakleta w mowach pożegnalnych Jezusa w J 13 - 17 w perspektywie antropologicznokulturowej i socjologicznej. Analizy te zostały poprzedzone przedstawieniem wyników współczesnych badań nad tożsamością i funkcją Parakleta w czwartej Ewangelii prowadzonych metodą historyczno-krytyczną. W perspektywie anrtopologicznokulturowej zostało wykazane, że Duch Paraklet w J 13 - 17 jawi się jako Pośrednik (Broker), który ma być reprezentantem i kontynuatorem misji Jezusa po Jego powrocie do Ojca. Natomiast przy użyciu modeli socjologicznych Bryana Wilsona i Mary Douglas zastosowanych do J 13 - 17 została ukazana aktywność Ducha Parakleta w introwersjonistycznej wspólnocie Janowego Kościoła.

Słowa kluczowe mowy pożegnalne Jezusa J 13 - 17, Paraklet, pneumatologia, socjologia, podejście socjologiczne, podejście antropologicznokulturowe

\section{Summary}

The Spirit Paraclete in Jesus' farewell discourses (John 13 - 17) from social-scientific and sociological perspectives

The article aims at analyzing the figure of the Spirit Paraclete in Jesus' farewell discourses in John 13 - 17 in a social-scientific and sociological perspectives. We preceded this task by presenting the results of research regarding the identity and function of the Paraclete in the Fourth Gospel in contemporary historical-critical exegesis. In a social-scientific aspect, we showed the figure of the Spirit Paraclete in John $13-17$ as a Broker who is to be the representative and continuator of the mission of Jesus after his return to the Father. Using the sociological models of Bryan Wilson and Mary Douglas, 
we analyzed the five statements of Jesus in John $13-17$ to show the activity of the Spirit Paraclete in the introversionist community of the Johannine Church.

Keywords Jesus' farewell discourse John $13-17$, Paraklete, pneumatology, sociology, social-scientific approach 
A. Uniwersytet Papieski

Ifét Jana Pawła II

o. W Krakowie 